\title{
BAŞKUMANDANLIK KANUNU
}

\author{
Yrd. Doç. Dr. Ahmet Emin YAMAN
}

Türk Kurtuluş Savaşı'nın en bunalımlı dönemlerindẹ birisi, Kütahya-Eskişehir Savaşları ile sonrası, bir başka deyişle Sakarya Savaşı öncesidir. Bunalımdan kurtuluşun tek yolu, Mustafa Kemal Paşa'nın ordunun başına geçmesi olarak görülmüştür. "Başkumandanlık Kanunu" ile Mustafa Kemal Paşa'ya verilen görevin niteliği; kanunun gündeme her gelişinde eleştirilere ve dokunaklı sözlere yol açmiştır. Her önemli konuda olduğu gibi, genelde, Meclis gizli oturumlarında görüşülmüş, oylanmış, alınan kararın Meclis açık oturumlarında tartışmasız kabul edilmesi yolu seçilmiştir. Nedeni, iç ve dış kamuoyuna, meclisin birlik halinde ve aynı düşüncede, kararlılık içinde olduğu izlenimini vermektir.

Başkumandanlık Kanunu, Büyük Millet Meclisi'nin 5 Ağustos 1921 günü yapılan iki gizli oturumundan sonra, Rıza Nur Bey (Sinop) ve arkadaşlarının teklifi, Şeref Bey (Edirne)'in, "Vatanın istihlâsı ve milletin istiklâlini istihdâf eden bu kanunun bilmünakaşa kabulünü rica" etmesi, oturum başkanı Dr. Adnan Bey'in tartışmasız ve görüşmesiz oylaması, oylamaya katılan 184 üyenin kabul oyu vermesi ile kabul edilmiştir ${ }^{1}$ :

"MADDE 1- Millet ve memleketin mukadderatına bilfiil vâzıulyed yegâne kuvveti âliye olan ve âzasından her birinin Kanunu Esasi ve Teşkilâtı Esasiye Kanunu ile hukuk ve masuniyeti teşriiyesị tabiati ile mahfuz ve şahsiyeti mâneviyesi Başkumandanlığ haiz bulunan Türkiye Büyük Millet Meclisi kuyudu âtiye ile Başkumandanlık vazifei fiiliyesine kendi Reisi Mustafa Kemal Paşayı memur eylemiştir.

MADDE 2- Başkumandan ordunun maddi ve mânevi kuvvetini âzami surette tezyit ve sevk ve idaresini bir kat daha tarsin hususunda Türkiye Büyük Millet Meclisinin

1 TBMM Zabit Ceridesi, C 12, İ: 62, Ankara TBMM Matbaasi, (5.8.1921), s. 18-19. Ự̧üncü oturumdur. Oturuma katılanların isimleri için bkz. s. 21-22. 
buna mütaallik salâhiyetini Meclis namına fiilen istimâle mezundur.

MADDE 3- Müşarünileyhe balâdaki mevat ile mevde sıfat ve salâhiyet üç ay müddetle mukayyettir. Meclis lüzum gördüğü takdirde bu müddetin inkızasından evvel dahi bu sıfat ve salâhiyeti ref'edebilir.

MADDE 4- İşbu kanun tarihi neşrinden itibaren meriyülicradır.

MADDE 5- İşbu kanunun icrasına Türkiye Büyük Millet Meclisi memurdur."

Kanunun kabulü üzerine söz alan Mustafa Kemal Paşa, Meclisin manevi şahsiyetinde bulunan Başkumandanlı görevini fiilen yerine getirmeye memur edilmiş olmak ve kendisine gösterilen güvenden dolayı teşekkür etmiş, milletimizi esir etmek isteyen düşmanları yeneceğimize ilişkin inancının hiçbir zaman sarsılmadığını söylemiştir. Tek ihtiyacı, Meclisin kendisini koruması ve milletin daima yardim etmesidir. Görevine fiilen başlamıştır ${ }^{2}$, Şeref Bey (Edirne), tarihi bir karar olduğunu belirtip, “... Her açıdan inkılâbın başında muazzam bir dimağ bitmiştir. Sen en büyük milletin büyük reisi... milletin senin omuzlarına yüklediği bu muazzam yükü, bu zafer alemini, bu milletin albayrağını, zafer merasimini ta ilerilere götüreceksin... sen kurtaracaksın. Tarihe namın altın harflerle geçecektir" der. Muhittin Baha Bey (Bursa), “.. Ümidimiz sizin mazide parlayan yüksek dehanıza merbûttur... Siz Anadolu'da bir Kemal yeri vücuda getireceksiniz ve onun karşısında başkalanı için bir zeval yeri olacaktır..."3 sözleriyle duygularını açıklar.

Kanun metni ve Mustafa Kemal Paşa'nın konuşması basında yayınlanmıs, bu tarihi kararın orduya ve milletimize yeni bir kuvvet, yeni bir ruh vereceği ${ }^{4}$ yazılmıștır. Tüm Anadolu'da sevinçle karşılanmış5, Paşa'nın Başkumandan olması, "zafer vardır kanaati" uyandırmıştır6. Hatta, Mustafa Kemal Paşa'nın Başkumandan olduğunu

2 a.g.e., s. 19.; Ayrıca bkz. Atatürk'ün Söylev ve Demeçleri, C, 1, Türk Tarih Kurumu Basımevi, Ankara, 1961, s. 173.

3 a.g.e., s. 20

4 Hakimiyet-i Milliye, "Tarihi Celse", (6.8.1921), s. 1

5 TBMM Gizli Celse Zabitları, C II, TBMM Basımevi, Ankara, 1980. s. 413-414. (Müfit Egfendi-Kırşehir).

6 a.g.e., s. 422. (Osman Bey-Rize) 
ajanstan duyan halk, "ne demek, Paşa Başkumandan değil mi idi ki, böyle bir görev veriyorsunuz"7 demiştir.

Konuyla ilgili gelişmeleri birkaç aşamada incelemek gerekmektedir. Gündeme gelmesini ve devamını gerektiren nedenler, ülkenin içinde bulunduğu durum ve zorunluluklardan kaynaklanmaktadır. Yunan ordusunun 10-25 Temmuz 1921 tarihleri arasında gerçekleştirdiği saldırı karşısında tutunamayacağımızı, büyük zarara uğıayacağımızı gören Mustafa Kemal Paşa, orduyu bir arada tutmak amacryla İsmet Paşa'ya, orduyu Sakarya'nın doğusuna kadar çekebileceği emrini 18 Temmuz günü cephe karargahunda vermiștir. En büyük sakıncası, kamuoyunda iç sarsıntı úyandırması ki, ilk duyarlılıklar mecliste görülür. ${ }^{8}$ Fevzi Paşa (Heyet-i Vekile Reisi), 23 Temmuz günlü gizli oturumda, Yunan saldırısı ve askeri, durum hakkında bilgi vermiş, bütün kuvvet ve malzemenin düzenli olarak Eskişehir hattına çekildiğini belirterek, “...Muzaffer olamadık ama muvaffak olduk..." der. Orduyu dinlendirmek ve takviye amacı güdülmüştür. Bir meydan savaşı ile düşmanı yeneceğimizi uman Fevzi Paşa, Meclis Ankara'da oldukca ordunun Ankara'yı düşünmek zorunda kalacağı için başka bir şey düşünemeyeceğini, düşmanin manevrasını buna göre yapacağını, merkezin Ankara'dan Kayseri'ye naklini hükümetin uygun gördüğünü belirtir. Düşman harekatı karşısında ordu serbest olmalıdır. ${ }^{9}$ Bunun üzerine çeşitli düşünceler ileri sürülmeye başlanır. Kararı yanlı̧ bulanlar, Ankara'dan çekilmenin halka ve orduya kötü etki yapacağını, orduda panik yaratabileceğini, Meclisin gitmemesini, halkı serbest bırakmasını isterler ${ }^{10}$. Bazıları ise, Ankara'da kalmanın da gitmenin de zararlı ve tehlikeli olduğunu, buna hükümetin, ordu kumandanlarının karar vermesi gerektiğini söylerler ${ }^{11}$. Birleşilen nokta, ülkenin büyük bir buhran içinde olduğu, askeri hareka-

7 a.g.e., s. 417. (Tunalı Hilmi Bey-Bolu); Mahmut Goloğlu, "Başkomutan Atatürk", Boğaziçi Üni. Uluslararası Atatürk Sempozyumu, İstanbul, 1981 s.7'de Mustafa Kemal Paşa'nın Samsun'a herhangi bir ordu kumandanı gibi değil bir Başkumandan gibi geldiğini ve sonraki çalışmalaıının da Başkumandan gibi olduğunu söyler.. "TBMM Başkanı iken de Başkomutandı".

8 Bu kararın yarar ve sakıncaları için bkz. Atatürk, Söylev (Nutuk)., CII, Türk Dil Kurumu Yayını, Ankara, 1978, s. 447.; Ayrica bkz. Selahattin Tansel, Mondıð’tan Mudanya'ya Kadà̀, C IV, 1. b., Milli Eğitim Bak. Yayını, Ankara, 1978, s. 94-99., Fahri Belen, Türk Kurtuluş Savașı, Kültür ve Tur. Bak. Yayını, Ankara, 1983, s. 327-330, 336-341.

9 TBMM Gizli Celse Zabıtları, C II, s. 101-103, 110-111.

10 a.g.e., s. 103. (Mustafa Durak Bey-Erzurum)

11 a.g.e., s. 106-107 (Vehbi Bey-Balıkesir, Hakkı Hami Bey-Sinop) ayrica bkz. s. 122 (30.7.1921), (Suat Bey-Kastamonu). 
tın eleştirilmemesi gerektiğidir ${ }^{12}$. Yalnız, “... memleket elden gider. Memleket gittikten sonra kim mesul olacaktır".

Hükümet şiddetle eleştirilerek, iş görmemek, çalı̧̧mamakla suçlanır. Ordunun ihtiyaçlarından söz edilerek, "Evvela, orduyu takviye etmek için ne yapmak lazım geliyorsa yapsınlar"'13 denir. "Cephe gerisi cephe kadar mühimdir". Fevzi Paşa, görevin güçlüğünün meclisi sinirlendirdiğini söyleyerek, subay eksikliği, elbise, çarık, techizat, ekmek, matara, ulaşım sorunlarına değinir. "Bunlar olmadan genel seferberliği ne yapacağız?" sorusunu sorar. Ve ilk kez, açık olmamakla beraber, "Baş Kumandan vekâleti"nden söz eder. Olağanüstü önlem gerekli midir, ordumuzu nasıl donatalım, takviye edelim sorunlarının düşünülmesini ister ${ }^{14}$.

30 Temmuz günlü gizli oturumda da, orduya müdahele etmeyi kimsenin düşünmediği görülür. Ordunun geri çekilmesinin doğruluğu, cephe gerisinin mutlaka güçlendirilmesi gerçeği ifade edilir. Yunanlılar, "kıştan önce bizi muharebeye zorlayacaklardır. Üç ayda birşey yapamazlarsa İngiliz gazetelerine göre Yunan davayı kaybetmiştir"15. Tunalı Hilmi Bey'e (Bolu) göre, bütün hayat kaynaklarımıza başvurmalıydık. Lütfi Bey (Malatya), Meclisin naklinin dış etkisinin de düşünülmesini ister. Ülkenin pek çok parçasını bıraktıysak, Ankara'yı da bırakabilirdik. Kahramanlık gösterip, 10-20 gün kalalım demek doğru değildir ${ }^{16}$.

Meclisin, durumu yerinde görüp incelemeleri ve bir rapor sunmaları için cepheye gönderdiği Rıza Nur (Sinop), Vehbi (Karesi), ve Mahmut Esat (İzmir) beylerin hazırladıkları rapor ve açıklamaları, 2. Ağustos günlü gizli oturum gündemine alınır. Açıklamalarına göre; ordunun geri çekilmesi muhtemel bir felaketi önlemiştir. Manevra gereği olduğu gibi, durumun zorluğunu gördükleri için ordu geri çekilmişti. Disiplini, kumandası, maneviyatı iyi idi. Geri çekilme esnasında kayıp, yaralı, esir vermiş, bazı malzemeyi bırakmıştı. Cephe

12 a.g.e., s. 104-107.

13 a.g.e., s. $108-109$.

14 a.g.e., s. $110-113$

15 a.g.e., s. 116-121 (30.7.1921). Ankara'nın üç hafta daha tehdit altında olmayacağı kabul ediliyor. s. 118.

16 a.g.e., s. 122, 124-127, Suat Bey, Meclisi Polatlı'ya taşımayı önerir.; Hakimiyet-i Milliye, "Fevzi Paşa'nın Beyanatı" (31 Teemmuz 1921), Düşmanlarımızın arzu ettikleri yerde savaşı kabul ettirme istekleri boşa çıkarılmıștır. Ordumuz düşmanın değil, bizim arzu ettiğimiz yerde savaşa girecek ve kesin darbeyi vuracaktır. 
gerisi hizmetler iyi yapılmamıştır; “...Askerin çarığı yoktur... çorapla kundura ister... bir kısmı çıplak ayaklı.. açıkta... soğuk oluyor, kaputu yoktur... su yoktur... mataraları eksiktir... fiçı yoktur.. 20 oranında süngüsü yoktur... kılıncı yoktur... 5000 civarında şehit vermiştir... maaş alamamışlardır... elbise \% 80'inde yoktur.. çadır yoktur... iç çamaşırı da yoktur..." Gazete ulaşamamakta, casusların propagandaları, özellikle de açlık ve susuzluk propagandası, askeri firara teşvik etmektedir. Cephe gerisi hizmetlerin iyi yapılamamasından hükümeti ve ilgili bakanlıkları sorumlu tutmuşlar, ihtiyaçların acele giderilmesini istemişlerdir. Meclis dağılmıştır, çekilmiştir propagandasının olumsuzluğundan söz ederek, Ankara'nın düşmesiyle davanın bitmeyeceği, fakat ülkenin zor duruma düşeceği belirtilmiş$\operatorname{tir}^{17}$.

Güçlüklerin atlatılabillmesi için, Mustafa Kemal Paşa'nın görevlendirilmesi yavaş yavaş gündeme getirilmeye başlanmış, bir milletvekili Mustafa Kemal Paşa'ya daha fazla yetki verilmesini istemiştir. Vehbi Bey, emek verilirse ihtiyaçların 15 günde sağlanabileceğini, "Başta Reis Paşa Hazretleri Başkumandanlığı deruhte etmek şartıyla" herkesin görevini yapacağını açıklamıştır. Mustafa Kemal Paşa, kendisine yetki verildiğinde, Meclisin kumandaya karışacağı, bunun da daha kötü sonuçlar doğuracağını anlatmaya çalışır. "... Meselâ yarın Ankara ahalisi öğleye kadar bana on bin don ve gömlek verecek desem, bu benim emrim olacak ve icra olunacaktır. Eğer onun için herşeyde kanun kitap ve satırlarının medlulüne mutabakatı arzu ediyor isek yapacak hiç bir şey yoktur"'18 diyerek te, istediği olağanüstü yetkilerin ilk sinyalini verir. Bazı sözlerden, istediği yetkiyi gündeme getirdiği sonucu çıkmaktadır ${ }^{19}$.

3 Ağustos günü Maliye Vekili Hasan Bey (Trabzon), mali durum hakkında bilgi verir. Bütçe açığı büyüktür. Meclisce yeni bir gelir kaynağı kabul edilse bile bunun etkisi ancak dört ay içinde görülebilecektir. Ordunun ihtiyaçları için belki, "tekâlif-i harbiye"ye başvur-

17 TBMM Gizli Celse Zabitları, C II, s. 132-133, 138-140, 142-144 (2.8.1921); ayrıca bkz. Kazım Özalp, Milli Mücadele 1919-1922 C I, Türk Tarih Kurumu Basımevi, Ankara, 1971, s. 189. Hakimiyet-i Milliye, "Cephedeki Mebuslarımızın Telgrafı" (29 Temmuz 1921). BMM'ne çekilen ve 28 Temmuz'da okunan telgrafta kamuoyunu olumlu etkileme amacı görülür. Bu amaç diğer günlerde sürdürülür: "Kuva-i Maneviyemiz", "Kahraman Ordumuza itimat" (3 Ağustos 1921), "Yunan Ordusunun Hali Perişandır" (4 Ağustos 1921)..

18 TBMM Gizli Celse Zabıtları, C. II, s. 141-142 (2.8.1921)

19 a.g.e., s. 141. M. Şeref Bey. 
mak zorunluluğu ortaya çıkacaktır. Birçok kanuna ihtiyaç vardır ve bunların sadece ikisi Meclisten çıkmıştır20.

4 Ağustos günü de gizli oturuma geçen Mecliste, hükümete daha fazla hareket serbestisi, yetki vererek; kısa zamanda ordunun istediği kuvveti hükümetin vermesi düşüncesi savunulur. Söz alan Salâhattin Bey (Mersin) şu düşünceleri ileri sürer ${ }^{21}$ :

“...Bu milleti azamî kuvvetini bir noktaya cemedelim ve bir zat hiç bir mani ve hail olmaksızın milletin bütün kuvvetini ve azmini menafie sevketsin, zaferi kazansin... kimdir? Meclisi Milli namına çalışacak bu zatın intihabı lazımdır... bir Başkumandan Vekili istiyoruz... Meclis Reisidir. Kumandayı idare etsin... milletin kuvvetini bir araya toplamak üzere bütün kuvvetimizi salâhiyeti namahdude ile verelim sual, cevap yok, bilahere neticeye göre mülahaza... ef'al ve amaline kimsenin müdahele etmiyeceği salahiyeti vasia ile Başkumandan vazifesini bir zatın deruhte etmesi lazımdır"

Dr. Mazhar Bey (Aydın) ortaya atılan ismi netleştirir, “... mevkiinden, şöhretinden istifade edilen bir zatı, mesela Meclis Reisini Başkumandanlık mevkiine getirme"yi teklif eder. Mustafa Kemal Paşa, "haysiyeti, mevkî̂, şöhreti itibarıyla" uygundur. Kumanda meselesi halledildikten sonra, "tekâlifi harbiye kanunu" da uygulanabilirdi. ${ }^{22}$

5 Ağustos 1921 günlü gizli oturumda, kendisine gösterilen güven ve yakınlığa teşekkür eden Mustafa Kemal Paşa, bir önerge sunar23: Başkumandanlığı, yararların çarçabuk elde edilebilmesi, ordunun maddi ve manevi kuvvetinin hemen artırılıp pekiştirilmesi ve yönetiminin bir kat daha sağlamlaştırılması için, Meclis yetkilerini fiilen kullanmak şartıyla kabul etmektedir. Ulusal egemenliğin ve meşruiyetin en sadık

20 a.g.e., s. $146-150(3.8 .1921)$
21 a.g.e., s. $158-159(4.8 .1921)$.

22 a.g.e., s. $162(4.8 .1921)$; Öncelikle Başkumandanlık meselesinin halledilmesi istekleri iyice artar. bkz. Söylev ,C II, s. 448; Tansel, a.g.e., s. 100. Muhalefetin, M. Kemai Paşa'nın Başkomuıan olmasını, tasfiyesi için bir fırsat saydığına ișare' eder; Şevket Süreyya Aydemir, Tek Adam Mustafa Kema 1 C. II, s. 471-478, 489-491. "Herşey bi.ti .. Hakikat bu!.." dendiği bir zamandır.

23 TBMM Gizli Celse Zabıtları, C II, s. 164; ayrica bkz. Söylev, C. II, s. 447-449.; TBMM Gizli. Oturumlarında Başkomutanlık Kanunu ve Tartışmalar, (Haz: Nevdet Öklem), Eğe Ưniv. Yayını, İzmir 19\&2, 134 s. 
kulu olduğunu, ulusa bir kez daha göstermek için de bu yetkinin üç ayla sinırlandırılmasını diler.

Mustafa. Kemal Paşa'yı daha önce Başkumandanlığa zorlayanlar bu kez, ünvan ve yetki meselesi üzerinde eleştirilere başlarlar. Herkesin birleştiği nokta, Başkumandanlığın Meclisin manevi şahsiyetinde olduğudur. Salâhattin Bey, "Başkumandan Vekili" denmesinde ısrar eder. Başkumandanlıktan mutlaka padişahlık anlamı çıkacağından içte ve dışta kötü etkilere, yanlış anlamalara yol açacaktır. Hakkı Hami Bey (Sinop)'in Başkumandanlığa itirazı yoktur. Vekil denmesi de yanlıştır. Anlayamadiğı "meclisin bütün salahiyetinden maksat..." tır. Tekliften, "üç ay zarfinda meclis yoktur" anlamı çıkmaktadır. Cevap veren Mustafa Kemal Paşa, Başkumandan Vekili'nin denenmiş, yıpranmı̧ bir kelime olduğunu, üstelik padişah crtaya çıkar vekil tayin etmedim derse ne olacağını sorar. Başkumandaniığın, Meclisin manevi şahsiyetinde olduğunu, böyle bir yetkiyi vermenin doğru olmadığını bildiği için üç ayla sınırlandırdığını belirtir. İstediği sınırlı yetki, "Yalnız ordunun maddi ve manevi kuvvetini tezyit ve ikmâlde ve ordunun sevkü idaresini tarsinde lüzum görülecek hususatı Başkumandanlığın derekâp yapmasıdır”. Zaman, her işte Meclise başvurulması için uygun değildir. Ordunun idaresi müzakere ve münakaşalarla olamazdı. Yoksa, Meclisin yetkilerini, mevcudiyetini yok edecek bir yanı hayaline getirmemişti ${ }^{24}$.

Şeref Bey, işin başına bir kudretin geçmesini istediklerini, ordunun da bir "Serdar-1 Ekrem" istediğini, Paşa'nın da orduya ilişkin yetki verirseniz kabul ederim dediğini hatırlatarak, bu yetki verilmedikçe başarılı olmasının mümkün olamayacağını tarihten örnekler vererek savunur. Ancak, önergeden şüpheye düşmüştür. " $\ldots$ biz bir Napolyon mu yaratıyoruz... diktatörlüğe doğru..." Paşa'nın gidemeyeceğini, milli iradenin hizmetkarı olmayı, padişah olmaya tercih edeceğini söyler. Milli egemenliği temsil eden meclis yetkilerini verme kudretinde değildi ama bugün ordunun başka türlü idare edilemeyeceği de açıktı. Hulusi Bey (Karahisar) kaygılıdır. "....korkarı̀z ki... Paşa hazretlerini hadisat başka bir mecraya doğru çevirmesin... Meclis salahiyetini hiçbir zaman bir şahısta bulundurmamalıdır"'25.

Mustafa Kemal Paşa, bu sözleri makul ve mantıklı bulduğunu belirtip, "Bahsettikleri şeyleri yapmak için... zannederim ki Meclis-

24 a.g.e., s. 165

25 a.g.e., s. $166-167,177-178$. 
ten salahiyet almaya lüzum yoktur". Bu görev, "emniyet ve itimat üzerine müesseses olabilir. Güveniniz yoksa böyle bir görev vermek muzirdir." Hızlı hareket etmeye, yetkili olmaya gerek vardır. "Mesele düşünmeğe değer çok düşününüz" der. Meclisin Başkumandanı olmak, Meclis adına görev yapmak istemektedir. "Büyük bir tehlike vardır, fakat büyük bir felaket başımıza gelmiş değildir". Harekatın sorumluluğunu alacak, orduyu sevk ve idare edecektir ${ }^{26}$.

Bu sözler üzerine, birçok milletvekilinin ve Tunalı Hilmi Bey'in endişeleri yok olmuştur. Veliddin Bey (Burdur), askeri yetkileri vermekte bir sakınca olmadığını, verilmezse bu nazik durumda iş görülemeyeceğini savunur. Orduya ilişkin yetkilerin bir kısmını, "Başkumandana devirden, "ruhu meşrutiyete muğayyir bir mana yoktur". Meclis, içinden birine ülke geleceğini ilgilendiren bir meslelede, üç ay için, manevi kişiliğinde olan bir yetkiyi vermek yetkisinde idi. Çünkü, Meclis bu gereği hissetmişti. Paşa'nın kurduğu müesseseyi yıkması ve diktiği ağacı kesmesi düşünülemezdi. Kanunun gerekliliği düşüncesi mecliste ağırlık kazanınca, Salahattin Bey bu kez, daha önce söylediklerini unutmuşcasına, durumun çok kötü olmadığını savunmaya başlar. "Acil ve pürtelaş birşey yoktur". Konu tartışılmalıdır. Kendisi haklarını feda etmeyecek, millete saklayacaktır. Paşa, Erkan-1 Harbiye Reisi veya Başkumandan Vekili olarak görev yapmalıdır 27. Oylamaya geçilir.

İkinci oturumda, Mustafa Kemal Paşa da, yasama ve yürütme yetkilerinin bir kişiye verilmesinde sakıncalar olduğunu, Meclisin bu konudaki duyarlılığından memnun olduğunu açıklar. Meclisin varlı̆gna herhangi bir saldırı olursa, her türlü yetkisinin kendiliğinden yok olacağını ve tabiki yapılan işlerin de milletin arzusuna göre olmayacağını belirtir. Yetkili kişinin, bir üye hakkında,' "keyfî, örfî muamele" yapmasının akla getirilemeyeceğini söyleyerek, bunu yok edecek tekliflerini siralar ${ }^{28}$.

Ülkenin içinde bulunduğu durum, kendilerine getirilen teklifler, milletvekillerinin değişik tepkiler göstermelerine neden olur. Mustafa

26 a.g.e., s. 168, 172-173; Yahya Akyüz, Türk·Kurtuluş Savaşı ve Fransız Kamuoyu 1919-1922, Türk Tarih Kurumu Basımevi, Ankara, 1975, s. 193-194. L' Eclair isimli Fransız gazetesinde yayınlanan İsmail imzalı bir yazıda, Ankara Hükümetine ateş püskürülmekte, 5 Ağustos'ta TBMM tarafından Mustafa Kemal'e verilen tam yetki, "Mustafa Kemal, Yunan bașarılarının Ankara 'da yarattığı panikten yararlanarak maskeyi attı, kendisini diktatör ilan etti"' şeklinde yorumlanmaktadır.

27 TBMM. Gizli Celse Zabitları, C II, s. 169-171., ayrica, s. 166, 168, 174-175.

28 a.g.e., s. 177. 
Durak Bey (Erzurum), konunun iki üç gün daha görülşülmesinden yanadır. Mesele orduyu ilgilendirdiğinden yetki vermek gereklidir. "Millet Başkumandanı" demek doğru olacaktır. Rıza Nur Bey, “. . . biz adeta bir padişah intihap ediyoruz... Bu Millet Meclisi olmadığı vakitte burada Hükümet de yoktur ve dava da bitmiştir" sözleri ile tepkisini dile getirir. Kanuna, "B.M.M'nin tadil ve feshi hariçtir... mebusların masuniyeti şahsiyesi... "maddelerinin konrnası gereğini ifade eder $^{29}$. Emin Bey (Eskişehir), ülkeyi Yunandan, clüşmandan kurtaracak Mustafa Kemal Paşa'ya bir süre için yetki vermekte, kani değildir ama "diktatör olarak icra etse" bile ülke için yarar görmektedir. "Hatta bendeniz, padişahlıktan yüksek makam olsa dahi veririm" derken, bir başka milletvekili, "Papulas başımızda çorba pişireceğine Paşa Hazretlerinin ayağı altında kalmaya razıyım... Bu Meclise rehber olan ve toplayan kendileridir... kuvveti bizzat Meclisten almıştır... Meclis kendi reisini kumandan yapiyor" 30 . der.

Oturum Başkanı, 183 oy kullanıldığını, kanunun 13 muhalife karşılık 169 oyla kabul edildiğini bildirir. Dileği, bu 13 kişinin açık oturumda olumlu oy vermeleridir. Mustafa Kemal Paşa, kendisine gösterilen güvene teşekkür etmiş, çok zorunlu olmadıkça hükümetin sarsılmamasını istemiş, bazı atamaları meclise surıarak ilk icraatına başlamışıı ${ }^{31}$. Meclis, açık oturuma geçerek kanunu ittifakla kabul eder.

Ülkenin geleceğini etkileyen bu kanun, sirasıyla 31 Ekim 1921, 4 Şubat 1922, 6 Mayıs 1922 tarihlerinde üçer aylık süreler için yenilenmiş, 20 Temmuz 1922 tarihinde yasada değişiklik yapılarak süresiz olması kararlaştırılmıştır. Başkumandan Mustafa Kemal Paşa, her üç aylık sürenin dolmasından önce, yetkinsinin sona ereceğini genelge ile ordu ve gerekli yerlere tebliğ ettiğini Meclise bir tezkere ile bildirmekte, hemen arkasindan bir kısım milletvekilince, kanunun tekrar yürürlüğe girmesine ilişkin teklifler sunulmaktadır ${ }^{32}$. Kanunun her gündeme gelişinde, gittikçe şiddetlenen, kırıcı tartışmalar yapılmakta, kanuna muhalefet edenlerin değişik gerekçelerle çoğaldığı görül-

29 a.g.e., s. $177-178,180$.

30 a.g.e., s. $177-179$.

31 a.g.e., s. 180-181 ve bkz. s. 182-185, 166-167.; Atamalar için bkz. TBMM Zabit Ceridesi, C 12, I: 62s. 19-21 (5.8.1921), Söylev, C II, s. 451.

32 Bkz. TBMM Zabit Ceridesi, C 14, I: 162, Celse: 2, TBMM Matbaasi Ankara, 1958, s. 5.; a.g.e., C 16 I: 154 , (4.2.1922) s. 202: a.g.e., C19, (4.5.1922) s. 520; TBMM Gizli Celse Zabıtları, C II, s. 413, 675, ve C III, s. 310; ayrica bkz. Hakimiyet-i Milliye, "Başkumandanllk" (29.10.1921), Süre bitimi hk. ordu kumandanlarına tebliğ. 
mektedir. İtirazın genelde, Mustafa Kemal Paşa'ya değil, verilen yetkiye olduğu belirtilmektedir.

Başkumandanlık Kanunu'nun 5 Kasım 1921'den itibaren üç ay daha uzatılması teklifi, gizli oturumda gündeme geldiğinde (31.10. 1921), kanunun etkili ve yararlı olduğu görüşüne herkesin katıldığ1 görülür. Müfit Efendi (Kırşehir), kanunun amacı ve etkilerini dile getirip Meclisin, savaşın en şiddetli ve en zor safhasında Mustafa Kemal Paşa'yı ordunun başına tayin ettiğini, bununla ordu ve milletin kuvvetlendiğini söyler. Askeri yönden, iyi savunmalarla düşman geri atılmıştır. Ankara'yı alamamış, geri çekilmiştir. Görev henüz tamamlanmamıştır, devam etmelidir. Siyasi yönden ise, görev uzatılmadığında dışta, "Türkiye Hükümeti gayesine ulaşmıştır ve daha ileri gitmekten vazgeçmiştir"33 denileceğini, bunun da zararlı olacağını savunur.

Hüseyin Avni Bey’e göre de, Mustafa Kemal Paşa vatanın tehlikede olduğunu görerek görevi kabul etmiş, etkili olmuş, iyi hizmet etmiştir. Amaca ulaşılmıştır. Başkumandanlığı bırakıp Meclis Başkanlığı görevini sürdürmelidir.. Başkumandanlığa karşı çıkışını da çeşitli nedenlere bağlar; “...Paşa Hazretleri yıpranmıştır... Fedakârlığını yaptı ve gösterdi... Maddi ve manevi kuvvetin bir zata tevdii bir millet için zaaftır... Meclis Başkanı olmakla sorumsuz, Başkumandan olmakla sorumluluğu vardır... Paşayı saklayalım, kıskanalım... Tekalif-i Milliye'de nisbetsizlikler olmuştur..." 34

Hüsrev Bey (Trabzon)'e göre, askeri durum görevin verildiği günden farkh değildir. Sorun, arazi kazanmak değil, düşman ordusunu yenmekti. Olağanüstü önlemler almak zorundaydık. Verilen yetkiden zarar görmemiş, yarar görmüştük, daha dả görecektik. Tunalı Hilmi Bey, görevin halkta olumlu etki bıraktığını belirterek, “... bugün dünkünden daha fazla tehlike karşısındayız" Dün yalnız harp tehlikesi varken, bugün siyasi tehlike de vardır. Keşke ikinci bir Mustafa Kemal Paşamız olsaydı der. Musa Kazım (Konya) Bey, üç ay önceki, “... ihtiyaç, zaruret ve illet aynen bugün de bakidir... Vazife bitmiş değil, zaferi kati istihsal edilmiş değil.." düşüncesindedir. Aynı düşüncede olan Abdullah Azmi (Eskişehir) Bey, milli davaya kendini, canını atan Mustafa Kemal'in yıpranmayacağını, üstelik Mecliste sorumlu olmayan kimsenin bulunmadığını söyler. Avrupa ve orduya etki edecek konu daha fazla uzatılmamalıdır. Mustafa Durak Bey, “... Başladığımız

33 TBMM Gizli Celse Zabıtları, C II, s. 413-415) (ayrica bkz. Cavid Bey-Kars). 34 a.g.e., s. $414-415$. 
işi bitirelim... Bugün salahiyet vermezsek, yarın fenalık gelirse kim mesul olacak?.."35 düşüncesiyle görevin uzatılması taraftarıdır.

Necip (Ertuğrul) Bey, Meclis yetkilerinin tamamını vermeye karşı olduğunu belirtir. Lütfi Bey (Malatya), ordunun saldırı gücünü kaybettiğinden, Tekalif-i Milliye'de suiistimallerden söz ederken, Salahatitin Bey bu kez konuya bir başka açıdan yaklaşır; Mustafa Kemal görevinin bittiğini bildirmiş, uzatmak gerekğini bildirmemiştir. "..kati zafere kani midirler? Kani ise Meclis başındaki kişinin yapılacak çok işi olmalı, burada bulunmamalı"dır. Kanun, fevkalade bir kanun olmak üzere ve tehlikeye karşı en lâzım ve zaruri bir çare olmak üzere kabul" edilmişti. Hayrı görülmüştü. Amaca ulaşılamadı ise, ne zaman, kaç ayda, kaç yılda ulaşılacaktı?” Düşman “... Ne için takip edilmiyor[du]... imkan yok mu idi acaba?"' Soramadıklarını, çünkü yetkilerinin hepsini verdiklerini belirtir. Önerilerini siralar: Mustafa Kemal Paşa'yı saklayalım, kıymeti olduğu zaman kullanalım...". Sorumluluklar paylaşılsın, "Mesul kimdir? Gözümüz görmüyor" derken bir yandan da, askeri durumun sslahının ne zaman biteceğinin başkumandanca açıklanmasını ister. Meclis Başkanlığı görevinin, başında bulunmalıdır. ${ }^{36}$

Cevap veren Osman Bey (Rize), böyle bir zamanda tartışmayı doğru bulmaz. Paşa ya askeri açıdan olağanüstü bir güven vardır. Taşrada, bunda zafer vardır kanaati uyanmıştır. Yıpranmış, yorulmuş sözleri yanlıştır. Saldırı, tartışması bile yapılmaması gereken bir konudur. Suat Bey (Kastamonu) şartların ilk günkü gibi olduğu düşüncesindedir. Sonra, "Başkumandanlığ Paşa kendisi talep etmedi. Meclisin talep ve ısrarı üzerine ihdas edilmiştir”. Sırn Bey (İzmit), yıpranma konusunda Paşa'nın şikayetçi olmadığını, görevi red etmediğini söyler. "Başkumandanlık meselesinden dönmek... siyasetimizi o dakika öldürmek demektir... Mustafa Kemal unvanı kendi başına bir ordudur... Sihirli bir kuvvettir." İhtimal dışı olmakla beraber, “... Başkumandanlığı kabul etmediği zaman bize hayır sonuna kadar bu işi yapacaksın, görevin budur demek düşer... gayemizin nihayetine kadar ordumuzun Başkumandanımsın." denilmelidir. Hariciye Vekili Yusuf Kemal Bey, “...Dışarıda Mustafa Kemal, Büyük Millet

35 a.g.e., s. $416-419$.

36 a.g.e., s. 418-422. Suiistimal konusu, Tekalif-i Milliye uygulamaları sözkonusu edilerek sık sık gündeme getirilmektedir; Daha sonraki günlerde de, hem Meclis Başkanı, hem Başkumandan olması sürekli eleştirilir. Hükümet'ten istifalar gündene geliı. Belen, a. g.e., s. 386 . 
Meclisi yekdiğerinden ayrılmaz şeylerdir..." düşüncesini savunur." "... Cenabi hak bu milletin mukadderatına Mustafa Kemal namını yazmıştır" 37 .

Verilen bir önerge ile, “...Kanunun 2. maddesiyle verilen salahiyete binaen iyi sonuç alınamamış, iktisadi kuvvetin üzerine çıkılmıştır" düşüncesi savunularak, eğer mutlaka görev verilecekse yetkilerinin alınması istenmiştir.

Görüşmeler sonucu, kanun teklifinin bütünü oya sunulmuş; 152 kabul oyuna karşılık, 12 red oyu verilmiş, isimsiz olduğu gerekçesi ile 2 oy geçersiz sayılmıştır ${ }^{38}$.

2 Şubat Perşembe günü, Ferit Bey ve arkadaşlarının Başkumandanlık Kanunu'nun uzatılmasına ilişkin kanun teklifi, gizli oturumda Meclise sunulur. Diğer oturumların aksine fazla söz alan olmaz. Sadece Hüseyin Avni Bey'in muhalefeti ile karşılaşılır. Daha önce söylediklerini tekrarlayan Hüseyin Avni Bey, Mustafa Kemal Paşa' nın davamızda, sorumlu bir mevkide olduğunu belirtir. Avrupalılar, "...zaman zaman harekatı milliyeyi kıymetinden düşürmek için bu harekatı, yalnız Paşa Hazretlerinin şahsına atfetmek suretiyle onu kıymetten düşürmek" istemektedirler. Dünya Türkiye'de, milletin ruhundan kopmuş bir Meclis görmek istemektedir. "...demesinler ki, memlekette Mustafa Kemal Paşa'nın şahsî arzusu hükümdardır... Sorumluluk isteyen işler yaptırılırsa, Mustafa Kemal Paşa'nın yıpranacağını, yıprandığını iddia eder. Mustafa Kemal Paşa'nın sorumluluğunu kabul etmediğini, buna göz yumulursa vatana ihanet olacağını ileri sürer. "... Paşa'nın hatırı için vatana ihanet... Paşa, başkalarının mesuliyetini üzerine almamalıdır.”. Vatanımızı seviyorsak, Paşa’yı yipratmamalıydık. "... Biz uyurken o uyumuyordu... Biz yine ismine Başkumandan diyelim, yine o ismi taşıyalım. Mesul kişiler olmalıdır. Müşkülata uğradığı konularda yetki verelim. Kendisine dünden daha çok güvenimiz vardır" der. "Muhalifsin"s sözünü reddeder. Gürültü

37 TBMM Gizli Celse Zabıtları, C II., s. 422-424, 426.

38 a.g.e., s. 428, 430-431. (Reddedenler: Yusuf Ziya (Bitlis), Hasan Hayri (Dersim Hüseyin Avni (Erzurum), Haydar Lütfi (İçel), Fuat (İzmit), Hulusi (Afyon), Dr. Abidin (Rize), Hüseyin Hüsnü (Sinop), İsmail Safa (Sinop), Muhtar Fikri (Sinop), Hakkı Hami (Sinop) beylerdir. Kabul ve red oyları arasında Salahattin Bey'in oyu yoktur. Oylama sonucu ilk açıklandığında 167 oy kullanıldığı, üçünün geçersiz olduğu belirtilir; ayrıca bkz, TBMM Zabit Ceridesi, C 14, I: 102, Celse: 2 (31.10.1921), Ankara, 1958, s. 5; Hakimiyet-i Milliye, "Başkumandanımızın Salâhiyetinin Temdidi" (1.11.1922). s. 1. Kanunun tartışmasız kabul edildiği duyurulur. Olumlu karşıllanmıștri. 
ve red sesleri arasında oylanan kanun maddeleri kabul edilir ${ }^{39}$. Konuya olumlu yaklaşarak, Mustafa Kemal Paşa'yı ve Meclisi, yetki alıp, vermekten vazgeçirmek eğilimi vardır. Kanunun fazla tartışılmaması ise Meclis'in açık oturumunda tartışma isteğinden kaynaklanmaktadir.

Nitekim, kabul edilmek üzere 4 Şubat günü Meclis gündemine geldiğinde, genel eğilimin aksine, farklı bir teklif sunulur. Başkumandanlığın üç ay daha uzatılmasını talep eden Mustafa Bey (Afyonkarahısar) farkı şöyle açıklar; “...Paşa Hazretlerinin kumandanlığına hiçbir muhalefet yoktur... hepinizden ziyade arzu ederim. Yalnız bütün ordunun kuvvetini tezyid emrinde, bütün Meclis namına fiilen... mezuniyet verilmesi hiçbir kanuna, hiçbir hukuka müstenid olamaz... Muvafik olamaz... harbe dair tedabiri derekap Meclise em.rederler. Meclis onu infaza mecburdur. Fakat bütün Meclisin reyini Riyasete vermek, kaideye, usule, hakka muvaffik değildir...”. Salahattin Bey bu teklifi destekler. Aynı yarar sağlanacaktır. "... Meclisi Âlinin salâhiyetini tenkis etmeyen bir şekildir... Salâhiyeti fevkâladeyi icabettiren esbab-1 âcele-i fevkâlade de yoktur... Bu Meclisi Âlinin salâhiyeti maliye, salâhiyeti kazaiye, salâhiyeti icraiyesine taallûk ve takyid edici bir kanundur..." 40 .

Bu teklif aleyhine tartışmaya girmeyip, doğrudan doğruya Ferid Bey'in teklifinin oylamaya sunulması üzerine "Cebren kabul edilmiştir", "Riyasetin istibdadı" şeklinde itirazlar olur. Oylama sırasında Mustafa Kemal Bey (Ertuğrul), kanuna herkesin ittifak etmesi gerektiğini , azınlık olmamasını, zira memleketin, milletin geleceğiyle ilgili olduğunu söyler ${ }^{41}$.

4 Mayıs 1922 günü, Başkumandanlık süresinin 5 Mayıs 1922 tarihinden itibaren üç ay daha uzatılmasına ilişkin kanun teklifi, gizli görüşülmek üzere Meclise sunulur ${ }^{42}$. Teklif, tartışma konusu olur ve üç görüş ortaya çıkar: Kanun, açik oturumda görüşülsün, gizli oturumda görüşülsün, Lâyiha Encümeni'ne gitsin.

39 TBMM Gizli Celse Zabıtları, C II, s. 675-677 (2.2.1922); bkz. Söylev C II, s. $462-463$. vd.

40 TBMM Zabit Ceridesi C 16 , İ: 154 (4.2.1922), TBMM Matbaası, Ankara 1958, s. $202-204$.

41 a.g.e., s. 204. İtiraz edenler Nafiz Bey (Samsun), Lütfi Bey (Siverek).; Hakimiyet-i Milliye "Başkumandanımızın Te mdid Müddeti (5.2.1922). Tartışmasız kabul edildiği yazılır. Bu karar ülkemizde, özellikle de ordumuzda sevinç ve şenlikle karşılanmıştır denir.

42 TBMM Gizli Celse Zabıtları, C III, s. 310 (4.5.1922)., Teklif 15 imzalıdır. 
Kanunun açık oturumda tartışılmasını isteyen Hüseyin Avni Bey önce, "... âleni kanunun gizli müzakeresinin manasını" sorar. Düşünceler açık oturumda söylenmelidir ki, “... Millet de anlasın... bilsin ki batağa girerken de hesap sorulacaktır... Bugün Başkumandanlığın yararı var $\mathrm{ml}$, yok $\mathrm{mu}$ ? Bu konuşulmalıdır." "salahiyeti teşriiye"yi kimseye vermemelidir. "Hafi celseler mühim meselelerde olurdu". Yani, konu pek öyle önemli değildi. Cemil Bey (Kütahya), önce Başkumandanlık Kanunu'nu olumlu bulduğunu, "Sonra, bir hükümdar hakkı olan Başkomutanlık vazifesini tevdiin doğru olmadığını düşünerek muhalif oy" verdiğini belirtir. "Çünkü, bu kanun ananemize, teamülü kadimize gayrı muvaffiktır”. Ali Şükrü Bey, Ağustos'ta bunun gerekli olduğunu, oysa şimdi durumun değiştiğini, Meclisin kendi hak ve yetkilerine tamamen sahip çıkması gerektiğini belirtir. Gizli oturuma gerek yoktur. Mehmet Şükrü Bey'e göre, “...Başkumandanlık Kanunu bitmiştir... bahsetmek doğru değildir... Meclis Başkumandan yapacak ise, Paşa Hazretlerini mi yapacaktır? Başkasını mı yapacak..."tır. Hulusi Bey, "Başkumandan olmazsa millet var" derken, Salih Efendi, “... Mustafa Kemal Paşa bizden o hakkı gaspetmek istiyorsa kendisini küçültür, biz de hakkı sarihimizi vermiyecek iken verirsek aptalız..." 43 der. Yetki tartışması yanında, hedefin Mustafa Kemal'i uzaklaştırmak olduğu anlaşılmaktadır.

Özellikle, Tahsin (Aydın) ve Yunus Nadi (İzmir) beyler, Başkumandanlık gibi nazik bir meseleyi mevcut koşullar altında açık oturumda görüşmenin doğru olmayacağını savunurlar ${ }^{44}$.

Ziya Hurşit (Lazistan) ile Salahattin beyler de bu kez, kanun teklifinin kurallara göre, "Lâyiha Encümeni"ne gitmesi gereğini dile getirip, zaman darlığının mazeret olamayacağını belirtirler ${ }^{45}$. Amaçları, süresi bir gün sonra sona eren kanunun çıkmasını engellemektir.

Meclisin, gizli oturumun devamina karar vermesi üzerine, kanun teklifi okunarak görüşmelere geçilir. Oldukca uzun süren konuşmalarda, muhalefetin etkin olduğu, daha çok yetkiler konusunda Meclisi kışırtarak, Mustafa Kemal Paşa'ya saldırarak kanunu engellemeyi amaçladıkları görülür. Dikkati çeken bir başka nokta da Başkumandanlık taraftarlarının suskunluğudur:

43 a.g.e., s. 310-312, 322. H. Avni Bey'i Ziya Hurşit Bey destekler

44 a.g.e., s. 313 ,

45 a.g.e., s. $314,311$. 
İlk sözü alan Salahattin Bey, kanunun uzatılma gerekçesini ve niçin Lâyiha Encümeni’ne gitmediğini sorar. Milletten "mal" kaçırmaktır. Hakları devretmek anlamsızdır. Olağanüstü zamanda yapılan fedakarlığa gerek kalmamıştır. Üstelik, yeni bir saldırı yapmak gibi bir düşünce de yoktur. "Ordumuzu idare edecek birçok kumandanlar vardır..." Meclis Başkanı, Meclis'teki görevine daha çok dikkat etmelidir. "... Milleti yaşatacak harp değildir... dünyada fert yoktur, millet vardır." Hüseyin Avni Bey, Meclisin yetkilerini kullanacak bir kişiyi dünyada görmek istememektedir. Bunu, "hakkı insaniyetim ve şerefi insaniyetim... mebusluk şerefim" biçiminde tanımlar;

"Eğer kendi şuuruma, aklıma itimat etmediğim gün namus benim için istifa etmektir... Deyiniz ki benim kudretim kafi gelmiyor, benim aklım kafi gelmiyor, ben kanun yapamam, sen de benim için yap diyen mebus varsa bana söyleyin... Başkalarının hukukuna tecavüz etmeye hakkım yoktur... millet, size salahiyeti... lüzumsuz yere ahara devretmek için vermedi... Siz zorla kafese, pençelere girmek istiyorsunuz, siz milleti rezil edeceksiniz... Büyük Millet Meclisinin fevkinde bir kuvvet göremem... Bir adama bin iş verilmez... hakkınızı kıskanınız... Emrü kumanda lazım. ise o başka bir kanundur... o günün ihtiyacı kaybolmuştur... Avrupa, cihan milletlere hürmet eder, şahıslara değil..." 46 .

Cevap veren Rauf Bey, emrivaki yapmak düşüncesinde olmadıklarını belirtir. Düşünülenin aksine ülke, "en buhranlı zamandadır. En hayati andadir..." Sürenin uzatılmaması ülke çıkarlarına zarar verecektir. Üç kez uzatılan kanun, hiçbirinde Lâyiha Encümeni'ne gönderilmemiştir. Şimdi de aynı işlem yapılmıştır. Kanunun ikinci maddesinin kaldırılması güvensizlik anlamına gelecektir. Yetkiyi azaltmak, görevini iyi yapmadı demektir. İçte ve dışta nasıl etki yapacaktır?47.

Ziya Hurşit Bey, teklifin Lâyiha Encümeni'ne gitmemesini ve gizli oturumu eleştirerek, “...Hafi celseye ait sözleri mebus aleni celsede de söyler ve katiyen menedilemez" der. Mehmet Şükrü Bey, ilk koşulların ve zorunluluğun ortadan kalktığını yeniler. Mustafa Kemal Paşa'nın yayınladığı "tekalif-i harbiye, tekalif-i milliye" halkı zarara sokmuş, suiistimaller yapılmıştır. Başkumandanlığa hala gerek

46 a.g.e., s. $315-317$.
47 a.g.e., s. $317-318$. 
vardır. Hiçbir ordu kumandansız olamazd1. Ancak, "Meclis artık zaruret karşısında ve muvakaten vermiş olduğu salahiyeti teşriiyeyi geri almalıdır... İkinci maddenin zarureti şimdi yoktur... İkinci madde kalırsa... Başkumandanlığın Meclise itimadı yok", anlamına gelecektir 48 .

Muhittin Baha Bey'in konuşması eleştirilere yanıt şeklindedir. Herşeyi yapmaya muktedir bir adam olmadığını; bazı haklarını denetim hakkını yerine getirerek, kendisinden daha iyi idare edeceklere vereceğini söyler. "Milletin menfaatına vatanın emrettiği icabatı siyaset ve harbiyenin emrettiği hakkı vermektir". Devredilen yetkilerin kötüye kullanıldığını Mecliste kimse söylememiştir. Yetkilerin eksiltilmesi, Başkumandan hakkında içte ve dışta tereddüt uyandıracak, kötü etki yapacaktır. Gizli oturumda söylenenlerin, açı oturumda söylenmesi de yanlıştı ve kötü etki yapardı. Gizli oturum çoğunluğun kararı idi. Kanun kabul edilmelidir ${ }^{49}$.

Görüşme yeterlilik önergesinin onaylanmasıyla tamamlanır ve maddelere geçilir. Aynı kişilerin benzer gerekçelerle kanuna, özellikle de kanunun ikinci maddesine karşı oldukları görülür. Askeri giderleri inceleyememekten yakınan Salahattin Bey, orduda tasarruf yapılabilineceğini, kanunun angaryayı reddetmesine rağmen angarya yaptırıldığından yakınır.. Başkumandanlık, ikinci madde kaldırılırsa, "bir zaruret halinde idame ettirilebilir" der. Şeref Bey "kanaati vicdaniyesini aleni celsede" bildireceğini, “...Bakal’m benim sözümü kim menedecek (yaşa sesleri - alkış)" diyerek, herkesin düşüncesini söylemesini ister. Sonuçta, ölüm-kalım davasında ordunun Başkumandansız olamayacağını, dünyanın hiçbir yerinde ordu kumandanının yetkilerinin sınırlanamayacağını savunur. Orduya karışılmamalı, Başkumandanlık Kanunu bütünüyle kabul edilmelidir. Vasıf Bey (Sivas)'e göre, her orduda bir Başkumandan bulunmaktadır, ayrıca bir kanuna gerek yoktur. Fazla ve lüzumsuzdur. Kanundaki olağanüstülük ikinci maddededir. Büyük buhranlar geçiren Fransa, Rusya ve Alman ordusu için yeni yetkiler içeren Başkumandanlık gerekmemiştir. Meclisler yasama yetkilerini vermemişlerdir. "... Gepheye memur olan bir Başkumandan, ordunun gerideki ihtiyacatına kumandan değildir. Zaman bize gösterdi. Yedi aydan beri... işte hala kıpırdayamadık ve kıpırdayamayacağız (bravo sesleri, alkışlar). Bir temasımız da kalmadı, olamadı, olamayacak zannederim ki bunun so-

48 a.g.e., s. 319-320.

49 a.g.e., s. $320-321$. 
nu gelmez, İyi düşünelim, nadim olmayalım, firsat elimizde iken selametle düşünelim. İkinci madde fazladır, kaldıralım" düşüncesini savunur ${ }^{50}$.

Hüseyin Avni ve Ali Şükrü beylerin çözüm yolları biraz daha farklıdır. İlkine göre, sona eren kanun görüşülemez, ancak yeniden görüşülerek kabul edilmesi mümkün olabilirdi. Diğerine göre ise, Başkumandanlık gerekli idi. İkinci maddeden Sakarya Savaşından beri yararlanılmadığı söylendiğine göre maddeye gerek yoktu. Yetkileri almak da, güvensizlik anlamına geleceği için iyi etki yapmazdı. $\mathrm{O}$ halde, “... Başkumandan Paşa, mademki teşri yetkiyi bizzat kullanmıyor, buna lüzum yoktur, ben bunu size verdim desinler, bitsin..." önerisini getirir. "Çünkü, Başkumandan, Meclisin müttefikan itimadına haiz olmalıdır. Yoksa iş göremez... Çare budur" der ${ }^{51}$.

Kazım Paşa, Müdafaa-i Milliye Vekaleti bütçesinin encümende incelenip, Meclisce kabul edildiğini, Meclise karşı kendisinin sorumlu olduğunu, bütçeye Başkumandanın müdahelesinin olmadığını söyler ${ }^{52}$. Fevzi Paşa, kuvvetli olmak için kanunun bütünüyle kabulü isteğini yeniler. İşi, kuvvetleri birleştirmek olan Başkumandanlığın zaafa uğratılmaması gerekmektedir ${ }^{53}$.

$\mathrm{Bu}$ arada, Salâhattin Bey, bir önerge olduğunu; ikinci maddenin kaldırılmasının oylanmasını isterken, Hüseyin Avni Bey, “... kuvvet Başkumandanlık Kanunu'nda değildir, milletin azim ve imanında, süngüsündedir..." diyerek muhalefetini sürdürür. Fevzi Paşa'yı Harbiye-i Umumiye Reisi yaparak ordunun başına koymuşlar, düşmana cevap vermesini istemişlerdir. "Başkumandanlık Kanunu ile vay halimize" idi. Vasıf Bey'de aynı doğrultuda konuşarak, Başkumandanlığın yerine, Erkan-i Harbiye-i Umumiye'yi ön plana çıkarma çabalarına girişiri ${ }^{54}$.

Görüşme yeterli görülerek oylamaya geçilir. Birinci madde kabul edilir. Salahattin Bey ve 15 arkadaşının, ikinci maddenin kaldırılmasına ilişkin teklifleri okunarak oylanır. Oylamaya katılan 176 üyenin; 91'i ret, 73'ü kabul, 12 'si çekimser oy kullanır. Teklif

50 a.g.e., s. $323-326$.

51 a.g.e., s. 325,327 .

52 a.g.e., s. 324.

53 a.g.e., s. 327.; Genelkurmay Başkanlığı ile Milli Savunma Bakanlığının BMM adına yaptığı görev hakkında bkz. Türk Silahlı Kuvvetler Tarihi TBMM Hükümeti Dönemi (23 Nisan 1923-29 Ekim 1923), C IV, 1. ks., Genkur. Basımevi, Ankara, 1984,

54 TBMM Gizli Celse Zabitlar, C III, s: 327-328. 
reddedilir. Kanun, ikinci maddeden başlayarak önce tek tek, sonra bütünüyle oylanır, çoğunluk yoktur sesleri arasında kabul edilir. "Aleni celseye" geçilir ${ }^{55}$.

Hüsrev Bey ve arkadaşlarının kanun teklifi tekrar okunur. Söz alan Hüseyin Avni Bey, gizli oturumda söylediklerini biraz daha yumuşatarak, Mustafa Kemal Paşa'nın görevini başarıyla yerine getirdiğini söyleyerek artık kanuna gerek kalmadığını savunur. Kanunun her gündeme gelişinde aynı şeylerin söylenmesi tepkiyle karşılanır ve yeterlilik önergesi üzerine oylamaya geçilir. Oy pusulaları toplanmaya başlandığında, muhalefetten yeni bir önerge gelir. Sonuçta, Mecliste görüşme çoğunluğu olmadığından oturum, Cumartesi günü toplanmak üzere tatil edilir ${ }^{56}$. Böylece kanunun yürürlüğe girmesi engellenir.

6 Mayıs Cumartesi günü, Hüseyin Avni Bey'in itirazına rağmen, Mustafa Kemal Paşa'nın teklifi üzerine gizli oturuma geçilmesi kabul edilir. Mustafa Kemal Paşa, Başkumandanlık Kanunu'nun uzatılmasına ilişkin görüşmelere rahatsızlığı nedeniyle katılamadığını, ancak öğrendiğini ve söylenenlerin hepsini gözden geçirdiğini, verilen oyları bile încelediğini belirterek söze başlar. Kanunun ilk çıkışını ve bunu izleyen aşamaları anlatır. Başlangıçtan sonuna kadar,' “. . . bu kanunun lüzumsuzluğundan yada tadil lüzumundan bahseden ve Başkumandanlığın mevcudiyetinden müşteki" olan kişiler vardır. Söylenenleri tek tek, iddia sahiplerinin isimlerini vererek cevaplandıracak-

55 a.g.e., s. 329. Salâhattin Bey ve arkadaşlarının teklifi: "Temdidi teklif olunan Başkumandanlık Kanunu'nun 2. maddesinin idamesi Meclisi Âlinin salâhiyeti teşriiyesini tahdit ve tenkis etmekte olduğundan bu maddenin lağvını ve lağvı hususunun tayini esami ile reye vaz'ını teklif eyleriz', s. 330 .

56 Zabıt Ceridesi, C 19, İ: 39 (4.5.1922), s. 520-522; Ayrıca bkz. Söylev ,C I) s. 478-485; Hakimiyet-i Milliye, "Mecliste: Başkumandanlık" (5.5.1922), s. 2. Konu, diğer uzatma haberlerinin aksine ikinci sayfada, önemsiz bir habermiş gibi verilir Gizli oturumda görüşülüp kabul edilmiş, açık oturumda oya sunulduğunda, Meclis'te çoğunluk kalmadığından Cumartesi tekrar görüşülmek üzere çalışmalarına ara vermiștir; Tansel, a.g.e., s. 118 Başkumandanlık yetkilerine oturumda bulunan 72 milletvekilinin karşı olduğunu belirtir. Oylamaya 170 milletvekilinin katılmış; 114 olumlu , 6 red, 23 çekimser oy kullanılmıştrr. Mecliste bulunan 27 milletvekili oylamaya girmemek suretiyle, "Nisâb-1 müzakerenin te'sisine ve inta-cı muameleye mâni" oldular.; Tansel, a.g.e., s. 119-120. Sonuç, istifaları gündeme getirmiştir.;TBMM. Gizli Celse Zabıtları, C III.. s. 353 (6.5.1922) Ragıp Bey (Kütahya) Çoğunluk varken oy belirtilmemesi eğiliminin Meclisi uçuruma sürükleyeceğinisöyler. 
tır. "...lüzumsuz bir mevkîin, bir makamın idamesi tarafları..." değildir ${ }^{57}$.

"Hakkın gaspı" iddiasına karşılık; hiç kimseye beni Başkumandan yapın, bu yetkileri bana verin demediğini, bütün Meclisin, "Başkumandan olacaksın", bazılarının, "başka çare yoktur" demeleri üzerine görevi kabul ettiğini, "Meclisi Âlinin tamamen, kısmen, cüzen salâhiyetini gaspedeyim" düşüncesinin hiçbir zaman aklına gelmediğini söyler ${ }^{58}$. Böyle birşey sözkonusu değildir. Doğru sesleri arasında, milletvekillerinin olağanüstü yetkilerle seçilmesine ve bütün ülkenin yazgısıná el koyacak bir nitelik kazanmasına en çok kendisinin çalı̧̧tığını ifade eder. Bunu başarmak için, pek çok arkadaşı ile fikir mücadelesi yapmış, bütün yaşamını, bütün şeref ve onurunu tehlikeye atmıştır. "Binaenaleyh bu benim eserimdir. Ben herkes gibi eserimi alçaltmakla değil, yüceltmekle görevliyim...". Salih Efendi hiç olmazsa beni de kendisi kadar bu Meclisin haklarıyla ilgili saysın cevabinı verir.

Mehmet Şükrü Bey, gizli celse ile gerçeğin gizlenmek istendiğini ima etmiştir." "... Bu meclis alelade bir meclisi teşriî değildir, bir Meclis-i Mebusan değildir. Yürütmeye de haiz bir hükümet vardır”. Hükümetin bütün kararlarını açıkladığı dünyanın neresinde görülmüştür? Bazı görüşler, kararlar vardır ki, bunları hemen millete söylemek, dünyaya ilan etmek uygun olmazdı. Başkumandanlık Kanunu da, ordu üzerinde ve özellikle düşman üzerindeki hükmü, nüfuzu açısından önemli görülmek ve gizli oturumda görüşülmek gerekirdi;

“...bir dava takip eden, bir ihtilâl yapan, bir inkılâp geçiren bu millet düşman karşısındaki ordulara Başkumandan tayin ederken, düşmanlara karşı bizim Başkumandan yapar, yapamaz, yaptı, yapamadı diye münakaşa eder.

57 TBMM Gizli Celse Zabıtları, C III, s. 334-354 (6.5.1922); ayrıca bkz. Söylev, C II, s. 478-485; Özalp, a.g.e., s. 231. 4 Mayıs günü Meclis'te gelișen olaylar Fevzi Paşa, Rauf Bey ve Kazım Paşa tarafından Mustafa Kemal Paşa'ya anlatılmış, Meclis tutanakları verilmiştir. Kanun uzatılmadığı için ordu kumandansız kalmıştır. Durum ordu kumandanlarına yazılır. İstifa etme konusu gündeme gelir. Ancak sonuçta, Mustafa Kemal Paşa'nın Meclis görüşmelerine katılması ve uzatma istemesi uygun görülür. Muhalefet biraz daha uzaklaşmış, görüşmeler dışarı sızmış, orduda yalan yanlıs görüşlere yol açmıştır. Fransız Miralay Mougin, hergün Meclise gelip, muhalif milletvekilleri ile görüşmekte, durumla yakından ilgilenmektedir.

58 Bkz. Söylev, C II, s. 447-448. Mustafa Kemal Paşa, kendisini ordunun başına geçirmek isteyenlerin düşünce ve amaçlarını ikiye ayırır. Komutanlığı, şimdilik üstüne almasında sakınca görenlerin düşünceierini aktarır. 
Sakıncaları olmaması için gizli celsede münakaşa tercih edilmelidir. Mamafih bizim Meclisimiz, dünyanın en demokrat bir Meclisidir. Bütün tenkitler yapılsın. Görülen sakıncalar ifade edilsin. Aleni celse talep etmek demek, arkadaşları bu serbestîi vicdandan, fikirden ve hürriyetten menetmek" demektir.

Yoksa, söylenecek sözlerin, yapilacak eleştirilerin milletten gizlenmesi amacı güdülmemişti.. Yararlı olan yapılmıştı. Mecliste açıkca, Başkumandan'ın rahatsızlığından söz edilmesi bile sakıncalı idi.

"Komedya oynatmiyoruz... kapılmayacağız" diyen Mustafa Kemal, Başkumandanlığa gerek yoktur, olsa bile önceki kadar değildir sözlerini de, "ordunun yalnız inhilâline yardım eden kuvvetler" olarak değerlendirir.

“.. Ben kanun neşretmedim. Başkumandanlar kanun neşretmezler. Emir verirler. Emirlerin tatbikatında suiistimal beyanındadırlar.. Fakat, emirlerimde suiistimal vardır demek caiz değildir..." Suiistimal edenleri cezalandırmak, hükümete ve sonuçta Meclise aittir. Herkes görevini yapmalıdır.

Temel olan ulustur. Ama, bireyler de vardır ve heyetler bütün ülkelerde işlerini bireylerle yapmaktadır. Ulus, bireylerden oluşmaktadir.

Saldıramayacağimızı söylemişler ve kendilerinin söyledikleri olmuştur. Oysa, saldıramayacak durumda olduğumuz, saldırının ertelenmesi gereği defalarca söylenmiş, gizli olarak ifade edilmiştir. Kararımız kesinlikle saldırmak ve düşmanı vatanımızdan atmaktır. "...Iİşte hala kıpırdayamad'k ve kıpırdayamıyoruz" sözleri ve bunun alkışlarla karşılanmasından büyük üzüntü ve acı duymuştur. "Ordunun kıpırdamamasını, kıpırdayamayacağını açıklamak ve bunu açıklayacak olan insanların alkışlanmış olması çok gariptir. Bunu da burada gömelím. Kimse işitmesin" der. Ordumuz mükemmeldir, ancak yeterli değildir. Uğraşılmaktadır. Ordunun başında bulunanlar, kendisinin orduya kumanda etmek mecburiyetinde olduğunu söylemektedir.

Siyaset yapılmasına, ne kendisi, ne de Başkumandanlık Kanunu engel değildir. Ki, "en büyük görevimiz topraklarımızda bulunan düşmanı tart etmektir. Bu milleti yaşatacak harptir. Başka çare yoktur. Bunun için bütün kudretimizi, kaynağımızı, varlığımızı orduya 
vereceğiz ve harp yapacak güçte olduğumuzu dünyaya tanıtacağız ve ondan sonra insanca yaşamak mümkün olacaktır" (Doğru sesleri).

Askeri giderlerin incelenmesini Başkumandanlık hiçbir zaman yasaklanmamıştır. Gelir kaynaklarımızla ne yapabileceğimiz endişesini herkesten çok duymaktadır. "Paramız nedir? Ne yapabiliriz.. biz ordumuzun mevcudiyetini mevcut paramızla mukayese edemeyiz Paramız vardır ordu yaparız, paramız bitti, ordu inhilâl etti... böyle bir mesele yoktur".

Kanunun ülkede angaryayı yasakladığı doğrudur. "Fakat tehlike bize herşeyi meşru gösteriyor. Ordunun ihtiyacı millete angarya yaptırmayı gerektiriyorsa bunu da yapacağız, en doğru kanun da bu olacaktır".

Devletler, değişik şekillerdeki hükümetlerle yönetilmektedir. Başlarında imparatorlar, krallar, çarlar, padişahlar, cumhurbaşkanları vardır. Bizim hükümetimiz bugün hiçbirine benzemeyen bir şekildir. Olayların zoru ile meydana gelmiştir. Her devletin şekline göre, Başkumandan bunlardan biridir. Meclisi olanlarda Meclis, yalnız "s1fat-1 teşriiyeye haiz"dir. "İsimlerini saydığımız adamlar da, en büyük kuvvet, en büyük kuvvet-i icraiye ve salâhiyet ihraz eden, işgal eden insanlardır." Başkumandanlık bunların uhdesindedir.. Başkumandanlar barış zamanında faaliyette bulunmazlar, ülke mevcut kanunlar dairesinde, ülke ileri gelenlerinin sorumlulukları altında yönetilirdi. Savaş ilan edildiği zaman, Çar, padişah bizzat kumandayı alır veya başka birini vekil tayin eder, "Hükümdarın iradesi ile tayin olunur"du. "Binaenaleyh, Başkumandanlığın mevcudiyeti hakkında kanun yoktur dediğimiz zaman işte bu irade-i hükümdari, çari, varit olabilir. Eğer, o kişiyi tayin eden bir Meclis olsa idi, o Meclisin ifadesine kanun derlerdi". Fakat şimdiye kadar dünyada böyle birşey olmamıştır. "Başkumandanların... vezaifi tayin olunmamısssa gayri muayyen olduğu içindir..." Askerlik ilmi Başkumandanlığın yetkilerini tayin etmezdi. Mevcut kanunlarda böyle birşey yoktur, gerek te yoktur.. Bizim şeklimizde ise, "Başkumandanlık sıfatı ve salâhiyeti Meclis-i Âilnizin şahsiyeti maneviyesinde mefhumdur... Meclis bir Başkumandan tayin etmiş ise onun ifadesi kanundur. O halde kanun vardır...". Bilmiyorum, gerek yoktur demesine rağmen, Başkumandanlık hakkında bir. kanun çıkarmak gereğini milletvekilleri ileri sürmüştür. "Hayır olmaz, kanun yapacağız., Meclis tayin edecektir" denmiştir:

"...Milletlerde herhangi bir adam Başkumandanlığı almışsa, o bunu kendiliğinden almışsa ve onun hakkında bir 
kanun yoksa onun adına "diktatör" derler. Yetkiyi Meclis vermişse, yetkisi geniş olsun, sunırlı olsun o görevi kendisi yapmamıştır. O görevi veren Meclis yaptırtmıştır. Binaenaleyh, Meclisin tevdi etmesi kanundur'".

Cepheye egemen olmak zorunda olan bir Başkumandan, cephe gerisindeki ihtiyaçlara, askeri birliklere de kumanda etmek durumundadır. Kumandan yapar denilince, oraya gidip kumandanlık yapar demek değildir; "Yaptırır demektir ve yaptırılır. Gözlerinle göremezsin, akıl ve ferasetinle göreceksin".

Müdafaa-i Milliye Vekaleti, Başkumandanlığın bakış' açısına göre hareket etmek zorundadır. "Ordusunun iaşesini, ilbasını, teslihini, ihzaratını düşünen ve ordulara kumanda eden insanın noktai nazarına göre hareket eden bir vekalettir..."

$\mathrm{Bu}$ açıklamalardan sonra, düşünüp karar vermenin Meclise düştüğünü belirten Mustafa Kemal Paşa, sorunun bundan ibaret olmadığını, bazı gerçekleri gözler önüne sermek zorunda olduğunu söyler:

Meclisin, Başkumandanlığın gerekliliğine inandığına kuşku yoktur. Ancak, muhaliflerin hiçbir temele dayanmayan davranışları, duygusallığın verdiği heyecanla herşeyi unutturabilecek bir sorundur. Bunun sonucu ne oluyordu? Başkumandanlık bir veya iki gün ne olacağı belirsiz bir durumda askıda bulunuyor, eğer kumanda ediyorsa, kanunsuz kumanda ediyordu. Görevinin bittiğini Erkan-1 Harbiye-i Umumiye Riyasetine ve Müdafaa-i Milliye Vekaleti'ne bildirmiş, Riyaset Reisi Paşa, kendisinin görevinin de bittiğini söylemiştir. "Ordu kumandasız mi kalacak, ne olacak? Binaenaleyh, b1rakamam ve birakmayacağım."

Kendisini iki gündenberi, kanuna aykıı Başkumandanlık yapmaya sevkeden muhalefetin ortaya çıkması, yalnız Başkumandanlık meselesinde değildi. $\mathrm{O}$ tesadüf etmişti. Başka bir şey tesadüf etseydi, zannınca aynı şey olacaktı. Uzun zamandanberi herhangi bir bakanlık için aday gösteremiyordu. 70 çekimser neden ileri geliyordu? “...Mebusların birinci görevi, öncelikle oyunu belirlemektir... Olumsuz veriniz. Kimden çekiniyorsunuz? .. Netice lazımdır. Bir memleket, bir ordu, bir millet duramaz, tereddüt içinde duramaz. Şu veya bu diye oy göstermek lazımdır”. Böyle giderse, “... Hükümet idare edilemez., ordu sevk edilemez, atâlete mahkum olur" $\mathrm{du}^{59}$.

59 Muhalefetin sayısı hk, bkz. Belen, a.g.e., s. 387. Söylev, C. II, s. 486 vd. 
"... Biz kanun adamıyı, biz herkesi ve herşeyi kanuna itaatlı k1lacağız. Herkesten önce kendimiz kanunsever olmalıyız”. Ben verdiğiniz yetkiyi kullanıyorum. "Siz o kanuna karşı, o kânunu tanımiyorsunuz...". O halde bana güveniniz yok demektir, ki "o da caiz değildi". Yapılması gereken, ya öncelikle kendisinin düşürülmesi ve yerine bir başka kişinin gelmesi veya kanunun yürürlükten kaldırılması idi. "Hiç olmazsa bir satır, mülgadır, ilga olmuştur" denilmeliydi. "... Ya itimat vardır, veyahut yoktur". Yapılan, "Hükümeti atâlete mahkûm etmek(tir)... Bu keşmekeşe, bu anarşiye behemahal son vermek lazımdır, böyle yürüyemeyiz" diyen Mustafa Kemal Paşa, Sakarya Savaşı öncesinden daha tehlikeli bir zamanda bulunulduğundan emin olunmasını isteyerek, düşününüz tavsiyesinde bulunur. “...Başkumandanlığın muhafazası ve idamesi o kadar lüzumlu... bırakamam demiştim. Yani, Meclis-i Âliniz lüzumu behemahal anlamıştır ve bana bıraktırmaz" der.

Fevzi Paşa, açıklamalarda bulunarak, Başkumandanlı̆̆ın orduda, içte ve dışta yapacağı etki nedeniyle muhalefete tahammül edemeyeceğini, Başkumandan çekilir çekilmez, kendisinin de çekilmek zorunda olduğunu belirtir. Hayati bir konuda parlamento oyunu yapılmamalıdır. Gizli oturumda herşey olabilirdi. Ancak, açık oturumlarda kuvvetli görünmek gerekiyordu. ${ }^{60}$

Daha önce, kanun ve Mustafa Kemal Paşa aleyhine konuşanlar bu kez, söz isteyerek, ortada bir anlaşmazlığın olmadığını, sözlerinin tutanaklara yanlış geçtiğini belirtirler. Karşılıklı yumuşama ortamı yaratıldığı görülür. “...Paşa'nın fedakarlığını bilmeyen yoktur... şüphe ile geldiğimiz günlerin semeresini görerek imanımız arttı... Paşa'yı biz yaşatacağız... düşürmek isteyenlerden değiliz... ölürse Yunanlı sevinir...", "Meseleyi kısa keselim...", “...Başkumandan emniyetle işine gitsin... ortada bir ihtilafimız yoktur...”, “...Herkesin kalbine nüfus etsinler... ademi itmat yoktur", muhalif oy verenler aydinlatılmalıdır biçiminde sözler söylerler. İkinci maddeye hala kuşkuyla bakmaktadırlar. Mustafa KemalPaşa'ya güvensizlikleri kesinlikle söz konusu değildir61.

İkinci madde hakkındaki kuşkulara karşı, Mustafa Kemal Paşa tekrar açıklama yapar: "Bu kanun dışı bir durum değildir ve Meclis tüm yasama yetkisini Başkumandana devretmiş değildir. Sırf orduyu takviye etmek için"dir. Meclis, isterse kanunu reddedebilirdi. Meclis,

60 TBMM Gizli Celse Zabitları, C III, s. 342.

61 a.g.e., s. 343-347. 
ordunun güçlenmesi için yetkiyi düzenleme gücüne sahipti. "...Menba kendisindedir. Verdiyse kendisi kanunla vermiştir. "Meclis tüm yetkilerini bir üç beş adama verebilirdi. Buna ilişkin 1916 yılında, Fransa ve İngiltere'den örnekler vardı. Vatanı kurtarmak, savaşta iyi sonuç almak için gerekli idi. Koşullar, ihtiyaçların zaman yitirmeye elverişli olmadı̆̆ını gösteriyordu.

Açık oturuma geçilmesi teklifi, Hüseyin Avni Bey'in, “Aleni celsenin neşredilmesi" teklifi ile birleştirilerek oylanır. Meclisin açık oturumunda oylanan kanun; 11 ret, 15 çekimsere karşllı 177 oy ile kabul edilir62.

20 Temmuz 1922 günü, Dr. Refik ve Operatör Emin beyler, Başkumandanlığ zorunlu kılan nedenlerin devam ettiği gerekçesi ile, Başkumandanlık Kanunu'nun, 5 Ağustos 1922 tarihinden itibaren üç ay daha uzatılmasını teklif ederler. Kanun tasarısı görüşülmeksizin oylanır ve kabul edilir ${ }^{63}$. Söz alan Mustafa Kemal Paşa, geçirilen en buhranlı günlerde Meclisin, savaş durumunun gerektirdiği kesin ve ciddi önlemleri alırken, Başkumandanlık Kanunu'nu çıkardığını ve özel bir madde ile milli irade ve kendi iradesinin önemli bir kısmını kendisine vererek, "istihsali zafere memur" olduğunu belirtir. Bu isabetli karar ve güven sonucu bugün, ordumuzun maddi ve manevi gücü, olağanüstü hiçbir önlemi gerektirmeyecek, milli amacı tam bir güvenle gerçekleştirecek aşamaya ulaşmıştır. Bu nedenle artık, böyle bir yetkiyi sürdürmeye gerek ve ihtiyaç kalmadığ kanaatindedir. "Hakimiyeti milliyenin bilâkaydüşart millette... Başkumandanlık sıfat ve salâhiyeti doğrudan doğruya Meclis-i Âlinizin şahsiyeti maneviyesinde mündemişçtir" Bu makam olsa olsa, Misak-1 Milli'nin özüne uygun kesin sonuca ulaşacağımız güne kadar sürerdi. Mutlu sona ulaşacağımıza kuşku yoktu. O gün İzmir, Bursa, İstanbul ve Trakya anayurda katılmı̧ olacaktı. Ayrıca, milletin bağınnda, özgür bir birey olmak kadar büyük bir mutluluk dünyada olamazdı. Gerçekleri bilen, gönlünde ve özünde manevi ve kutsal tatlardan başka zevk taşımayan insanlar için, ne kadar yüksek olursa olsun, maddi makamın hiçbir değeri yoktu ${ }^{64}$.

62 Kanuna kabul, ret, çekimser oy verenler bkz. TBMM Zabıt Ceridesi, C. 19, I: 40 , (6.5.1922), s. 529-530.

63 TBMM Zabit Ceridesi, C I, I:77, (20.7.1922) Ankara, 1959., s. 430.

64 a.g.e. s. 430-431; Atatürk'ün Söylev ve Demeçleri, C.V. s. 23-24.; Kazım Karabekir, İstiklal Harbimiz, Yüce Yayınları, Istanbul, 1990, s. 1104; İsmail Habib, "Atatürk'ten Hatıralar ve Ibretler" Cumhuriyet (6 Ocak 1939). Mustafa Kemal, gücünü Başkumandanlıktan almadığını belirtir. "Yaşasın Başkumandan! ne demektir? Neden Mustafa Kemal! demiyorsun da Başkumandan diyorsun. 
Ali Rıza Bey (İstanbul), son gelişmeyi değerlendirerek, yasama yetkisine gerek kalmadığını belirten Mustafa Kemal Paşa'nın millete ve Meclise büyüklüğünü gösterdiğini söyler. Asıl sorun, Başkumandanlığın ordumuz için bir ihtiyaç, bir askeri zorunluluk olmasıdır. Milli amaca ulaşmak için, Paşa, ordunun başına geçmeli ve Başkumandanlık zaman ile sınırlandırılmamalıdır. Zaman, "doğrudan doğruya zaferi nihainin istihsaline bağlı" olmalıdır. Ve buna uygun kanun teklifini sunar 65 :

"1- Millet ve memleketin mukadderatına bilfiil vazıulyed yeğane kuvveti âliye olan ve âzasından her birinin Kanunu Esasi ve Teşkilâtı Esasiye Kanunu ile hukuk ve masuniyeti teşriîyesi tabiatiyle mahfuz ve şahsiyeti mâneviyesi Başkumandanlığa haiz bulunan Türkiye Büyük Millet Meclisi, Başkumandanlık vazifei milliyesine muvakkaten kendi Reisî Müşir Gazi Mustafa Kemal Paşa Hazretlerini memur etmiştir.

2- Meclis lüzum gördüğü takdirde bu sıfat ve selâhiyeti ref' eder.

3- İşbu kanun tarihi neşrinden muteberdir.

4- Issbu kanun Türkiye Büyük Millet Meclisi tarafindan icra olunur.

Durak Bey (Erzurum) biraz farklı düşünmektedir: Henüz fiiliyata girmemiştik. Mustafa Kemal Paşa bu işe nasıl başlamışsa, sonuca götürmeli ve Meclise öyle teslim etmeli idi. “...Y Yarın bir aksi zuhur ederse o zaman kim mesul olacak? Yarın kalkacak diyecektir ki; ... şunu yaptım, bunu yaptım, nihai zafere vasıl olacaktım fakat elimden salâhiyeti aldını. Siz yaptınız, siz ettiniz diyecektir... Başkumandanlık, zafer sağlanana dek alınmamalıdır (alan yok sesleri)" 66 . Teklifi, kanunun ilk şekli ile kabul edilmesidir. Sonuçta, Ali Rıza Bey'in önergesi kabul edilir. Mustafa Kemal Paşa, ikinci madde ile sahip olduğu yetkilerden vazgeçmiş, Başkumandanlık Kanunun'daki zaman sınırlaması kalkmıştır.

Görüldüğü üzere Başkumandanlık Kanunu, Yunan saldırısı sonucu, ülkenin büyük tehlike altında bulunduğu; herşeyin bittiği dü-

65 TBMM Zabit Ceridesi, a.g.e., s. 435.

66 a.g.e., s. 435; , Hakimiyet-i Milliye, "Mustafa Kemal Paşa Hazretleri Amal-1, Milliyenin Tahakkukuna Kadar Başkumandan", s. 1.; Söylev C II, s.485; Aydemir, a.g.e. C. III, s. 571 vd. Özalp., a.g.e., s. 230-231. 20 Temmuz öncesi gelişmeler için. 
şüncesinin güçlenip yaygınlaştığı; ordunun ihtiyaçlarının hemen karşılanması, güçlendirilmesi, daha iyi sevk ve idare edilebilmesi için hızlı karar verilip uygulanması zorunluluğunun ortaya çıktığı ve Meclisce, Mustafa Kemal Paşa'dan başka bir çözüm görülmediği bir zamanda gündeme gelmiştir.

Mustafa Kemal Paşa'ya güven esasına dayanan kanun, tüm eleştirilere karşın, ülkenin kurtarılması hedefine hizmet etmiş, amacına ulaşmıştır. Mustafa Kemal Paşa'nın kanunun verdiği yetkiyi bir amaç olarak değil, araç olarak kullanması, muhalefetin eleştirilerini boşa çıkarmakta, temelsiz kılmaktadır. Üstelik, "milli egemenlik" ve "milli irade'ye" dayandırılan tàrtı̧ma, öneri ve eleştirilerinde samimi olmadıkları; amaçlarının, kendi amaçlarını gerçekleştirmek için engel gördükleri Mustafa Kemal Paşa'yı yıpratmak, dışlamak, çalışamaz duruma getirmek olduğu anlaşılmaktadır.

Başkumandanlık tartışması, dolaylı yoldan da olsa, 20 Temmuz 1922'den sonra da devam etmiştir. Önce, Başkumandan Mustafa Kemal Paşa'nın siyasi konularda anlaşma devletleri ile ilişki kuramayacă̆1, sonra da askerlik görevinin sona ermiş olduğu düşüncesini, işlerin Bakanlar Kurulu'nca yürütülmesi gereğini ileri sürerek savunmuşlar; gücünü etkinliğini kırmak istemişlerdir. Bu girişimleri boşa çıkarılınca eylemlerini, Mustafa Kemal Paşa'yı vatandaşlık haklarından yoksun etmeyi hedefleyen girişime kadar götüreceklerdir ${ }^{67}$.

Mustafa Kemal Paşa'nın, Lozan Antlaşması'nın imzalanmasına kadar Başkumandanlık ünvanını kullandığı görülür. Kanunun kaldırıldığı hakkında bir karar yoktur. Ancak; 29 Ekim 1923'te Cumhuriyetin ilanı ve Mustafa Kemal Paşa'nın Cumhurbaşkanı seçilmesi ile kendiliğinden son bulduğu kabul edilmelidir.

67 Bkz. Söylev, C II, s. 486, 529; TBMM Gizli Celse Zabıtları, C III) s. 787-791, $795-800(18.9 .1922)$ ve s. $833,836(27.9 .1922)$. 